\title{
Review
}

\section{New Perspectives on the Neuropathology in Huntington's Disease in the Human Brain and its Relation to Symptom Variation}

\author{
Henry J. Waldvogel ${ }^{\mathrm{a}, \mathrm{b}}$, Eric H. Kim ${ }^{\mathrm{a}, \mathrm{b}}$, Doris C.V. Thu ${ }^{\mathrm{c}}$, Lynette J. Tippett ${ }^{\mathrm{d}}$ and Richard L.M. Faull ${ }^{\mathrm{a}, \mathrm{b}, *}$ \\ ${ }^{a}$ Faculty of Medical and Health Sciences, Department of Anatomy and Radiology, University of Auckland, Auckland, \\ New Zealand \\ ${ }^{\mathrm{b}}$ Centre for Brain Research, University of Auckland, Auckland, New Zealand \\ ${ }^{\mathrm{c}}$ Brain Mind Institute, École Polytechnique Fédérale de Lausanne, Switzerland \\ ${ }^{\mathrm{d}}$ Department of Psychology, University of Auckland, Auckland, New Zealand
}

\begin{abstract}
We review recent investigations regarding the relationship between selective neurodegeneration in the human brain and the variability in symptom profiles in Huntington's disease. Huntington's disease is a genetic neurodegenerative disorder caused by an expanded CAG repeat in exon 1 of the Huntingtin gene on chromosome 4, encoding a protein called huntingtin. The huntingtin protein is expressed ubiquitously in somatic tissue, however, the major pathology affects the brain with profound degeneration in the striatum and the cerebral cortex. Despite the disease being caused by a single gene, there is a major variability in the neuropathology, as well as major heterogeneity in the symptom profiles observed in Huntington's disease patients. The symptoms may vary throughout the disease course and present as varying degrees of movement disorder, cognitive decline, and mood and behavioral changes. To determine whether there is an anatomical basis underlying symptom variation, recent studies on the post-mortem human brain have shown a relationship between the variable degeneration in the forebrain and the variable symptom profile. In this review, we will summarize the progress relating cell loss in the striatum and cerebral cortex to symptom profile in Huntington's disease.
\end{abstract}

Keywords: Huntington's disease, human brain, pathology, symptoms, cortex, basal ganglia

\section{INTRODUCTION}

Huntington's disease (HD) is an autosomal dominant neurodegenerative disorder associated with an unstable expansion of a CAG trinucleotide repeat in the first exon of the Huntingtin gene [1]. In humans, exon 1 of the Huntingtin gene normally varies between 6-35 CAG repeats, but individuals with more than 36 CAG repeats are at risk for HD. There is a correlation between the number of CAG repeats and the age of

*Correspondence to: Richard L.M. Faull, Faculty of Medical and Health Sciences, Department of Anatomy and Radiology, University of Auckland, Private Bag 92019, Auckland, New Zealand. Tel.: +64 9 9236708; E-mail: rlm.faull@ auckland.ac.nz. onset and disease severity, such that cases with CAG repeat lengths of 36 to 60 typically manifest symptoms in mid-life, whereas CAG repeat lengths of $>60$ results in more severe juvenile form of the disease [2-8].

The mutant huntingtin is expressed ubiquitously in somatic tissue; however the pathology of HD is most extensively localized in the forebrain. In the brain the neuropathological changes are characterized by extensive degeneration of the striatum (caudate nucleus and putamen) and the cerebral cortex together with involvement in other regions such as the globus pallidus, thalamus, hypothalamus, and white matter $[9,10]$. The disease is characterized clinically by involuntary choreiform movements accompanied 
by progressive cognitive impairment and emotional disturbances [11]. One of the most important features of the disease, which has been highlighted by recent studies, is the highly variable nature of the neuropathology and symptomatology in affected individuals despite the single gene etiology of HD [12-15]. Although the age of onset and severity of disease generally correlate with the CAG repeat length, the distinct symptom phenotypes expressed in HD affected individuals show no significant correlation with respect to the size of the CAG expansion. Consequently, there is much interest in whether there are any underlying pathological differences in HD brains which may account for symptom heterogeneity. This review will specifically focus on the possible relationship between symptom profiles of adult onset HD and the variable pattern of degeneration in the striatum and the cerebral cortex [12-15].

\section{CLINICAL FEATURES AND VARIATION IN SYMPTOMS}

Huntington's disease is characterized by symptoms affecting motor control, cognition, and behavior. However, the pattern of symptoms exhibited by each individual during the course of the disease as well as at the time of onset can vary considerably. The symptoms typically emerge in mid-life; however the disease can manifest from early childhood to late in life $[11,16]$. The disease duration is typically 10-20 years.

The onset of motor symptoms is used to define the clinical onset of HD. Development of involuntary, choreiform movements are one of the most distinctive and well recognized symptoms of $\mathrm{HD}$, which was clearly documented in George Huntington's original work in 1872 [17]. Although useful for diagnosis, chorea is a poor marker of disease severity. Most patients initially display hyperkinetic movements that are progressively replaced by a more hypokinetic (akineto-rigid) syndrome in which bradykinesia, rigidity and dystonia predominate. In addition, the patient's ability to speak and swallow is also often affected thus leaving the patient susceptible to aspiration pneumonia [18-20].

The cognitive disorder begins insidiously with the loss of mental flexibility and progressive decline of intellectual processes that can lead to profound dementia. Early cognitive defects include impaired concentration, dysfunction of short-term memory and impairment of executive functions [21, 22]. As the disease progresses these deficits develop into a more widespread dementia, with the deterioration of verbal skills such as speech and difficulty in visuospatial functioning [23-25].

Behavioral and psychiatric symptoms are common, but unlike cognition do not show a stepwise progression with disease severity [26]. There is a wide range of associated mood and neuropsychiatric complications. HD patients are afflicted with depression, dysphoria, agitation, irritability, labile mood, apathy, and anxiety $[27,28]$. Also, a disproportionately high prevalence of obsessive-compulsive symptoms, sleep disturbances, personality changes, psychotic symptoms, and suicidal tendencies have been previously reported [29-32].

The onset of clinical symptoms pertaining to the motor, cognitive, and behavioral domains and disease course of HD, once manifest, can vary substantially between individual HD patients. For example, some patients show major motor dysfunction at clinical onset with minimal changes in mood or cognitive functions, while at the other extreme, others show major mood and cognitive related changes early in the disease course with minimal motor dysfunction until late stages of the disease. Moreover, remarkable symptom differences have been observed in monozygotic twins that have the same genetic mutation and environmental factors [33-36]. The intricate interaction of this particular genetic defect with innumerable environmental factors and modifier genes may produce a wide range of different possible phenotypes among HD cases [37].

\section{NEUROPATHOLOGY OF THE HUMAN BRAIN}

The specific symptoms of HD have been related to the neuropathology, which is characterized by neuronal loss in different functional regions of the brain. An early account of neuropathological abnormalities was described by Meynert in 1877 who proposed that chorea may be explained by lesions in the corpus striatum [38]. The brain weight in end-stage HD is about $300-400 \mathrm{~g}$ less than the average brain weight of $1300-1500 \mathrm{~g}$. This gross atrophy of the brain principally results from profound shrinkage of the striatum (caudate-putamen) and thinning in the cerebral cortex $[9,14,15]$. The hippocampus, hypothalamus and thalamus are also affected $[9,10,39]$ and the corpus callosum is often atrophic. Most interestingly as detailed below, recent analyses of post-mortem human HD tissue suggest that the variation in clinical symptoms in HD is strongly associated with the variable pattern of neurodegeneration in the striatum and cerebral cortex $[12,13]$. 


\section{Neuropathology in the basal ganglia}

Gross examinations of post-mortem human HD tissue and in vivo neuroimaging techniques reveal that the disease produces a striking bilateral atrophy of the striatum $[9,40,41]$ which generally has an ordered and topographical distribution. The tail and body of the caudate nucleus generally show more degeneration than the head. The pattern of degeneration in the caudate nucleus and the putamen usually progresses in the caudo-rostral and simultaneously in the dorso-ventral and medio-lateral directions [9]. The extent of striatal degeneration established by Vonsattel [42] has been the hallmark grading system to indicate the severity of HD disease pathology. The Vonsattel grading system consists of five grades (0-4) of severity based on both the macroscopic and microscopic histological findings in the striatum. The most affected neuronal populations in the striatum are the GABAergic medium-sized spiny projection neurons (MSNs) that constitute $90-95 \%$ of the striatal neuronal population. The MSNs that project to the external segment of the globus pallidus (indirect pathway) are the most vulnerable to the disease process $[43,44]$. This population of neurons expresses enkephalin and dopamine D2 receptors and degenerates in advance of the MSNs that project to the internal segment of the globus pallidus and substantia nigra pars reticulata (direct pathway) that express substance P, dynorphin and dopamine D1 receptors [45]. The degree of striatal atrophy is, in part, associated with the degeneration of other nonstriatal basal ganglia regions, e.g., the globus pallidus, substantia nigra, subthalamic nucleus $[9,40]$. What is especially interesting is that, as detailed in the next section, recent findings suggest that the pattern of striatal cell death shows regional differences between cases in the functionally and neurochemically distinct striosomal and matrix compartments of the striatum.

\section{Striosome-matrix compartmental degeneration in the striatum and its relation to symptom profile}

The mammalian striatum is divided into two major interdigitating compartments first identified using acetylcholinesterase (AChE) by Graybiel and colleagues [46]. The smaller AChE-weak striosome compartment is identified by high concentrations of distinctive neurochemical markers (neurotensin [47], LAMP [48], dopamine D2 receptors [49], GABA receptors and kainate receptors [50-53], and substance $P$ and enkephalin [54]) while the larger matrix compartment is characterized by high concentrations of other neurochemicals (AChE, tyrosine hydroxylase, somatostatin, the calcium-binding proteins calbindin, calretinin, parvalbumin, and the glutamatergic NMDA and AMPA receptors [51, 54-61]).

In $\mathrm{HD}$, changes in the neurochemicals found in the striosome and the extrastriosomal matrix compartments have been reported. Some studies suggest that neuronal loss and gliosis shown by GFAP staining first appear in the striosomes, indicating that the neurons in striosomes may be more vulnerable at an early stage of HD or lower grades of the disease than those in the matrix [62-64]. However other studies show a preferential loss of neurons and neurochemical markers in the matrix compartment with clear sparing of the striosomes [50, 65, 66]. These findings detailing the heterogeneous pattern of compartmental striatal degeneration in HD are interesting as studies in the rodent and primate brains show that the striosome and matrix compartments have different patterns of connectivity and suggest that the two compartments are functionally different. Evidence from tracing studies suggests that the striosome compartment contains MSNs that receive inputs from the limbic system and these in turn project to the dopamine-containing neurons in the substantia nigra pars compacta [67-69]. Therefore the striosome compartment is thought to play a major "limbic" processing role in modulating mood and other related functions of the basal ganglia. Conversely, the matrix compartment receives inputs from especially the sensori-motor and associative cortices and hence, it is postulated to play a major role in the control of movement $[56,70]$.

Extending these observations, Tippett and colleagues [13] have shown a differential pattern of degeneration in the two striatal compartments in different HD symptom cases. Some cases showed a selective striosomal loss of striatal neurons, enkephalin and $\mathrm{GABA}_{\mathrm{A}}$ receptors (Fig. 1B), others showed selective cellular and $\mathrm{GABA}_{\mathrm{A}}$ receptor loss in the matrix compartment (Fig. 1C). Other cases showed a mixed striosomal/matrix pattern of degeneration. Most importantly, this differential compartmental pattern of striatal degeneration between cases correlated generally with the variable symptom profiles between cases; most notably there was a significant association between profound degeneration in the striosomes and pronounced mood symptoms in the patients (Fig. 1B). By contrast, cases with marked degeneration primarily in the matrix compartment often had major motor symptoms (Fig. 1C), although the matrix findings were not statistically significant. These findings particularly the relation between striosome degeneration and mood 

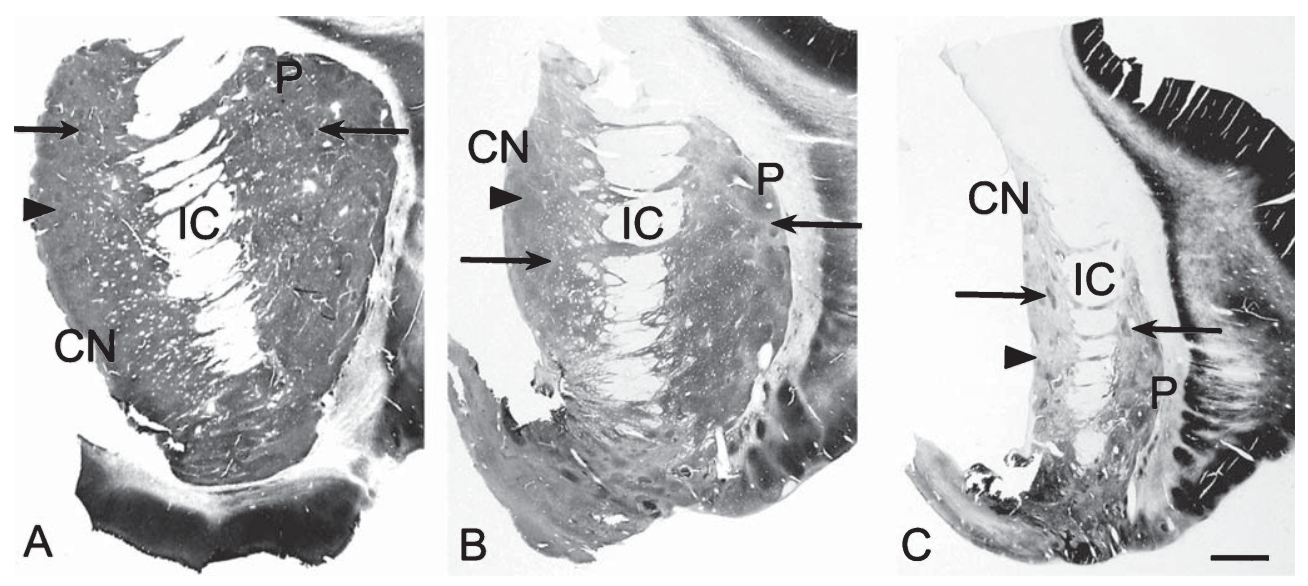

Fig. 1. Comparison of the patterns of $\mathrm{GABA}_{\mathrm{A}}$ receptor immunostaining in the striatum of a normal case (A) and two HD cases (B, C),

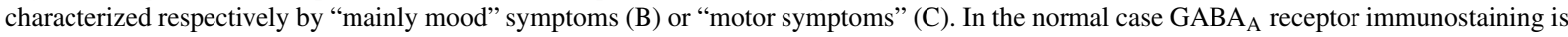
distributed throughout the striatum (caudate nucleus and putamen) with higher densities in the striosome (arrow) and moderate densities in the matrix (arrowhead) compartments. In the $\mathrm{HD}$ case which had predominant mood symptoms there is a major loss of $\mathrm{GABA}_{\mathrm{A}}$ receptors in the striosomes (B); whilst the case which has predominant motor symptoms shows extensive receptor loss in the matrix compartment with relative preservation of striosome receptors $(\mathrm{C})$. (In the photomicrographs the matrix is indicated with an arrowhead and the striosomes with an arrow). $\mathrm{CN}=$ caudate nucleus; $\mathrm{IC}=$ internal capsule; $\mathrm{P}=$ putamen. Scale bar $=5 \mathrm{~mm}$.

disturbance suggest that the different compartmental patterns of cell death and degeneration in the HD striatum could contribute significantly to the variability in HD symptomatology.

\section{Neuropathology in the cerebral cortex and its relation to symptom profile}

The cerebral cortex shows heterogeneous degeneration throughout different regions of the cerebral cortex in HD. In the cerebral cortex there is overall loss in cortical volume, cortical thinning, neuronal cell loss, neuronal morphological changes, glial cellular changes [12, 14, 15, 41, 71-77]. Recent advances in neuroimaging and detailed pathological analysis of the cerebral cortex in HD cases have also provided further new perspectives on the clinical heterogeneity in HD. Several imaging studies showing striatal and cortical atrophy have been correlated with cognitive deficits such as attention, working memory and executive functions [23]. DTI and tractography studies have shown that the motor circuit between the sensory-motor cortex and the striatum are most affected in HD [78], and these morphological changes correlated with cases showing mainly motor symptoms. Also landmark MRI studies by several authors have demonstrated progressive regional thinning of the cortical grey and white matter in both symptomatic and premanifest HD patients which correlate with varying cognitive, visuomotor and motor deficits $[14,15,79,80]$. These findings indicate that cortical changes may contribute to the heterogeneity of symptoms previously ascribed solely to basal ganglia alterations $[15,79,81-83]$. Importantly, the pioneering correlative MRI studies by Rosas and colleagues $[14,15]$ showed that cases with a prominent choreiform movement disorder presented a major thinning in the sensory-motor cortical region. Furthermore, the cases with more prominent dystonia, bradykinesia and rigidity demonstrated an overlap of thinning in the sensory-motor cortex region but additional thinning was shown in more anterior portions of the frontal cortex including pre-motor and supplementary motor areas.

Our recent detailed quantitative study using stereological cell counting in the post-mortem human HD cortex has complemented and expanded the neuroimaging studies by providing a cortical cellular basis of symptom heterogeneity in HD [12]. In particular, HD cases who were dominated by motor dysfunction showed a major total cell loss (28\% loss) in the primary motor cortex but no cell loss in the limbic cingulate cortex, whereas cases where mood symptoms predominated showed a total of 54\% neuronal loss in the limbic cingulate cortex but no cell loss in the motor cortex. This suggests that neuronal loss and alterations in the circuitry of primary motor cortex and anterior cingulate cortex may contribute respectively to impairments of motor and mood functions in HD (Fig. 2). 


\section{Aggregates in $H D$}

The cell death in HD is accompanied by the presence of intranuclear and cytoplasmic aggregated forms of mutant huntingtin $(\mathrm{mHtt})$ in neurons throughout the brain. The role of inclusions in cell death is controversial as there is evidence for both deleterious and protective effects [84-87]. These protein aggregates are thought to be formed by associations of polyglutamine (polyQ) regions which act as a 'polar zipper' [88, 89]. The immunohistochemical analyses of post-mortem human HD brain has demonstrated the presence of aggregates that can form neuronal intranuclear inclusions (NIIs) or cytoplasmic and neuropil extranuclear inclusions (NEIs). NIIs tend to be round, oval or rod shaped, larger than the nucleolus and more frequent in juvenile than adult onset cases. In contrast, the neuropil aggregates occur more frequently than NIIs in adult cases and tend to be round or oval and may be arranged in thin extensions along a process [90-93]. The inclusions are present prior to symptomatic development of the disease in the human brain and found throughout the cortex, but less frequently in the striatum [92-96]. Within the cortex, the cells tend to display combinations of nuclear and cytoplasmic as well as neuropil aggregations [95] with the highest levels of intranuclear inclusions found in juvenile cases which tend to have relatively very high CAG repeat
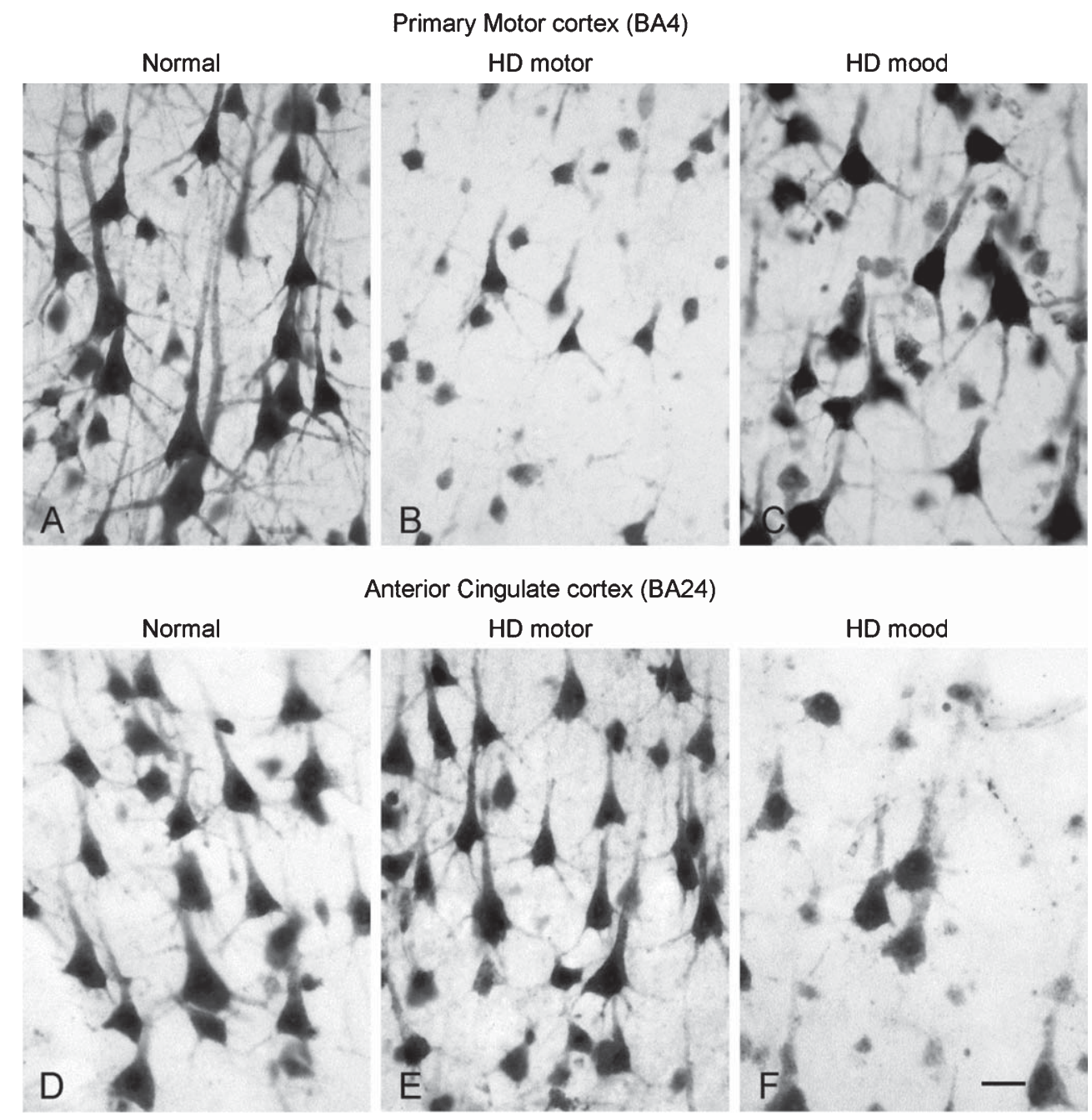

Fig. 2. Photomicrographs illustrating the pyramidal neurons in layer III in the primary motor cortex (A-C) and anterior cingulate cortex (D-F) of normal (A, D) and Huntington's disease cases (B, C; E, F). The images illustrate cases with "mainly motor" (B, E), and "mainly mood" (C, F) symptom profiles. In the motor cortex, the case showing predominant motor symptoms (B) shows major cell loss compared to the normal case. In the cingulate cortex the case with predominant mood symptoms $(\mathrm{F})$ shows major cell loss compared to the normal case. $\mathrm{Scale}$ bar $=30 \mu \mathrm{m}$, modified from Thu et al. [12]. 
numbers [92]. Elucidating the exact molecular mechanisms for mHtt cytotoxicity has been a challenge. The mHtt aggregates are mostly ubiquitinated and are enriched in truncated polyglutamine containingfragments generated by several proteases, however the precise mechanisms responsible for the toxicity of these proteolytic products remain elusive. It is generally thought that $\mathrm{mHtt}$ confers a toxic gain-of-function to elicit a cytotoxic cascade. Indeed, overexpression in various types of cells is cytotoxic [97, 98]. However, the soluble, non-aggregated forms of $\mathrm{mHtt}$ in tissues have been implicated more recently to be the neurotoxic culprit $[84,99-101]$. There is also evidence to suggest that the aggregated forms of $\mathrm{mHtt}$ may have no effect or even be protective to cells [84, 101, 102]. The substances that are toxic to cells generally elicit a myriad of effects and therefore it is difficult to isolate which are primary, secondary or tertiary [103-105]. In addition, the expression of huntingtin does not reflect the distribution of selective vulnerability [106]. Some have even presented the view that cortical neurons may actively destroy MSNs, rather than these cells being vulnerable to $\mathrm{mHtt}$ itself [107]. Nevertheless, inclusions play a role in HD and are commonly used as biological markers for the testing and development of new therapeutic strategies aimed at reducing inclusion formation [108-111].

\section{POSSIBLE MECHANISMS OF NEURONAL DEGENERATION IN HD}

The prevailing questions in the field of HD pathology are: how and when pathological neuronal loss occurs; whether the progressive loss of neurons in the striatum is the primary process or is consequential to cortical cell dysfunction; and also how these changes relate to symptom profiles. Striatal neurons are thought to degenerate through excitotoxic processes or metabolic stress, but whether this is caused by intrinsic mechanisms in those neurons or through excitotoxic mechanisms originating from dysfunction of the cortical pyramidal neurons which project on to the striatum is still unclear. What is clear is that the diverse symptomatology of HD patients appears to have a morphological correlate where the regional distribution of neuronal dysfunction and loss correlates to the pattern of symptomatology in individual cases [12-15]. As the basal ganglia and cortex play an important role in modulating motor and mood functions, the consequent disruption of circuits between the cortex and basal ganglia and neuronal death in both regions must play a major role in symptom phenotype. It has been suggested that cortical changes [83, $112,113]$ are fundamental to the onset and progression of the HD phenotype. For example, the anterior cingulate cortex is the first cortical area to develop nuclear inclusions in the R6/2 HD mice [86] and is the site of ubiquitin-reactive dystrophic neurites in HD patients [114]. Also, in post-mortem HD brains [90, $91,115]$ the accumulation of mutant huntingtin is consistently found more frequently in the cortex than in the striatum, and abundant neuropil aggregates have been detected in the cortex of presymptomatic HD cases $[92,116]$. The widespread changes in the cortex are further supported by a microarray study in the human primary motor cortex where $3 \%$ of the genes (1482 genes) were differentially expressed in the HD cases [117]. These studies showed greater abnormalities in mRNA expression in the motor cortex than in the prefrontal association cortex, suggesting a distinct regional pattern of transcriptional alteration in the cortex of HD. In the cerebral cortex, the large projection neurons in layers V and VI are the most affected [71, $72,74,118]$ and are the principal neuronal type which projects to the striatum. Therefore, as others have suggested, dysfunction and loss of neocortical neurons may contribute to the pathogenesis of cell death in the striatum via the corticostriatal pathway.

Indeed, one of the prevailing mechanisms from mouse models of cell death in HD proposes that early changes in the corticostriatal pathway maybe a major contributing factor to the initiation of the pathogenesis in HD [119-121]. The corticostriatal neurons provide a major excitatory glutamatergic input onto the MSNs in the striatum and dysfunction of the corticostriatal neurons in HD mouse models [122, 123] leads to excess glutamate release in the striatum resulting in NMDA receptor-mediated excitotoxic MSN damage [124]. Furthermore, dysregulation of glutamate release is compounded by loss of dopamine D2, CB1, mGluR2/3 and other presynaptic receptors regulating glutamate release at corticostriatal terminals. Another adverse effect of corticostriatal dysfunction is reduced release of brain-derived neurotrophic factor (BDNF) a growth factor necessary for striatal neuron survival [125]. The mHtt has been shown to reduce the production and transport of BDNF in the cortex via the corticostriate pathway [126-131]. Also, an early dysregulation of the $B D N F$ gene due to mutant huntingtin has been suggested to disrupt microcircuitry in the cerebral cortex in a cellular in vitro model of HD leading to dysfunctional signalling in the cerebral cortex [132]. Other mechanisms contributing to cell death 
in HD include environmental and epigenetic factors transcriptional dysregulation, oxidative stress, changes in neurotransmitters, and breakdown of cellular and vesicular transport mechanisms in neurons of the striatum and cerebral cortex [129, 133-135].

\section{CONCLUSION}

Overall, these studies show that the different patterns of degeneration in the basal ganglia and the cerebral cortex is highly variable and correlates to the variable symptom profiles in HD. Convergent evidence supports both cell-autonomous and non-cell autonomous processes in neuronal dysfunction and degeneration in both the cerebral cortex and striatum. While there is currently no cure, this contemporary evidence suggests that possible genetic therapies aimed at HD gene silencing should be directed towards intervention at both the cerebral cortex and the striatum in the human brain.

\section{ACKNOWLEDGMENTS}

Neurological Foundation of New Zealand Human Brain Bank, Health Research Council of New Zealand, Mathew Oswin Memorial Trust, Freemasons of New Zealand, Auckland Medical Research Foundation.

\section{CONFLICT OF INTEREST}

None declared.

\section{REFERENCES}

[1] Huntington's Disease Collaborative Research Group. A novel gene containing a trinucleotide repeat that is expanded and unstable on Huntington's disease chromosomes. Cell. 1993;72(6):971-83.

[2] Snell RG, MacMillan JC, Cheadle JP, Fenton I, Lazarou LP, Davies P, et al. Relationship between trinucleotide repeat expansion and phenotypic variation in Huntington's disease. Nature genetics. 1993;4(4):393-7.

[3] Nance MA. Clinical aspects of CAG repeat diseases. Brain Pathology. 1997;7(3):881-900.

[4] Penney JB Jr, Vonsattel JP, MacDonald ME, Gusella JF, Myers RH. CAG repeat number governs the development rate of pathology in Huntington's disease. Annals of Neurology. 1997;41(5):689-92.

[5] Andresen JM, Gayan J, Djousse L, Roberts S, Brocklebank D, Cherny SS, et al. The relationship between CAG repeat length and age of onset differs for Huntington's disease patients with juvenile onset or adult onset. Annals of Human Genetics. 2007;71(Pt 3):295-301.

[6] Andrew SE, Goldberg YP, Kremer B, Telenius H, Theilmann $\mathrm{J}$, Adam S, et al. The relationship between trinucleotide
(CAG) repeat length and clinical features of Huntington's disease. Nature genetics. 1993;4(4):398-403.

[7] Duyao M, Ambrose C, Myers R, Novelletto A, Persichetti F, Frontali M, et al. Trinucleotide repeat length instability and age of onset in Huntington's disease. Nature genetics. 1993;4(4):387-92.

[8] Squitieri F, Frati L, Ciarmiello A, Lastoria S, Quarrell O. Juvenile Huntington's disease: does a dosage-effect pathogenic mechanism differ from the classical adult disease? Mechanisms of ageing and development. 2006; 127(2):208-12.

[9] Vonsattel JP, DiFiglia M. Huntington disease. Journal of neuropathology and experimental neurology. 1998; 57(5):369-84.

[10] Petersen A, Bjorkqvist M. Hypothalamic-endocrine aspects in Huntington's disease. Eur J Neurosci. 2006;24(4):961-7.

[11] Nance MA. Huntington disease: clinical, genetic, and social aspects. Journal of Geriatric Psychiatry and Neurology. 1998;11(2):61-70.

[12] Thu DCV, Oorschot DE, Tippett LJ, Nana AL, Hogg VM, Synek BJ, et al. Cell loss in the motor and cingulate cortex correlates with symptomatology in Huntington's disease. Brain: A Journal of Neurology. 2010;133(Pt 4):1094-110.

[13] Tippett LJ, Waldvogel HJ, Thomas SJ, Hogg VM, van Roon-Mom W, Synek BJ, et al. Striosomes and mood dysfunction in Huntington's disease. Brain: A Journal of Neurology. 2007;130(Pt 1):206-21.

[14] Rosas HD, Liu AK, Hersch S, Glessner M, Ferrante RJ, Salat $\mathrm{DH}$, et al. Regional and progressive thinning of the cortical ribbon in Huntington's disease. Neurology. 2002;58(5):695701.

[15] Rosas HD, Salat DH, Lee SY, Zaleta AK, Pappu V, Fischl $\mathrm{B}$, et al. Cerebral cortex and the clinical expression of Huntington's disease: Complexity and heterogeneity. Brain: A Journal of Neurology. 2008;131(Pt 4):1057-68.

[16] Walker FO. Huntington's disease. Lancet. 2007;369(9557): 218-28.

[17] Huntington G. On chorea. Med Surg Reporter. 1872;26:31721.

[18] Young AB, Shoulson I, Penney JB, Starosta-Rubinstein $\mathrm{S}$, Gomez F, Travers H, et al. Huntington's disease in Venezuela: neurologic features and functional decline. Neurology. 1986;36(2):244-9.

[19] Mahant N, McCusker EA, Byth K, Graham S. Huntington's disease: clinical correlates of disability and progression. Neurology. 2003;61(8):1085-92.

[20] Berardelli A, Noth J, Thompson PD, Bollen EL, Curra A, Deuschl G, et al. Pathophysiology of chorea and bradykinesia in Huntington's disease. Mov Disord. 1999; 14(3):398-403.

[21] Snowden JS, Craufurd D, Thompson J, Neary D. Psychomotor, executive, and memory function in preclinical Huntington's disease. J Clin Exp Neuropsychol. 2002;24(2):133-45.

[22] Ho AK, Sahakian BJ, Brown RG, Barker RA, Hodges JR, Ane $\mathrm{MN}$, et al. Profile of cognitive progression in early Huntington's disease. Neurology. 2003;61(12):1702-06.

[23] Montoya A, Price BH, Menear M, Lepage M. Brain imaging and cognitive dysfunctions in Huntington's disease. J Psychiatry Neurosci. 2006;31(1):21-9.

[24] Kirkwood SC, Su JL, Conneally P, Foroud T. Progression of symptoms in the early and middle stages of Huntington disease. Arch Neurol. 2001;58(2):273-8.

[25] Lawrence AD, Watkins LH, Sahakian BJ, Hodges JR, Robbins TW. Visual object and visuospatial cognition in 
Huntington's disease: implications for information processing in corticostriatal circuits. Brain: A Journal of Neurology. 2000;123(Pt 7):1349-64.

[26] Thompson JC, Snowden JS, Craufurd D, Neary D. Behavior in Huntington's disease: Dissociating cognition-based and mood-based changes. J Neuropsychiatry Clin Neurosci. 2002;14(1):37-43.

[27] Paulsen JS, Ready RE, Hamilton JM, Mega MS, Cummings JL. Neuropsychiatric aspects of Huntington's disease. J Neurol Neurosurg Psychiatry. 2001;71(3):310-4.

[28] Rosenblatt A, Leroi I. Neuropsychiatry of Huntington's disease and other basal ganglia disorders. Psychosomatics. 2000;41(1):24-30.

[29] Anderson KE, Louis ED, Stern Y, Marder KS. Cognitive correlates of obsessive and compulsive symptoms in Huntington's disease. Am J Psychiatry. 2001;158(5):799-801

[30] Cummings JL, Cunningham K. Obsessive-compulsive disorder in Huntington's disease. Biol Psychiatry. 1992;31(3):263-70.

[31] Baliko L, Csala B, Czopf J. Suicide in Hungarian Huntington's disease patients. Neuroepidemiology. 2004;23(5): 258-60.

[32] Robins Wahlin TB, Backman L, Lundin A, Haegermark A, Winblad B, Anvret M. High suicidal ideation in persons testing for Huntington's disease. Acta Neurol Scand. 2000;102(3):150-61

[33] Georgiou N, Bradshaw JL, Chiu E, Tudor A, O'Gorman L, Phillips JG. Differential clinical and motor control function in a pair of monozygotic twins with Huntington's disease. Mov Disord. 1999;14(2):320-5.

[34] Anca MH, Gazit E, Loewenthal R, Ostrovsky O, Frydman M, Giladi N. Different phenotypic expression in monozygotic twins with Huntington disease. Am J Med Genet A. 2004;124A(1):89-91.

[35] Gomez-Esteban JC, Lezcano E, Zarranz JJ, Velasco F, Garamendi I, Perez T, et al. Monozygotic twins suffering from Huntington's disease show different cognitive and behavioural symptoms. Eur Neurol. 2007;57(1):26-30.

[36] Friedman JH, Trieschmann ME, Myers RH, Fernandez HH. Monozygotic twins discordant for Huntington disease after 7 years. Arch Neurol. 2005;62(6):995-7.

[37] Wexler NS, Lorimer J, Porter J, Gomez F, Moskowitz C, Shackell E, et al. Venezuelan kindreds reveal that genetic and environmental factors modulate Huntington's disease age of onset. Proceedings of the National Academy of Sciences of the United States of America. 2004;101(10):3498-503.

[38] Meynert T. Discussion to Fritsch. 1877;4:47.

[39] Aziz NA, Pijl H, Frolich M, van der Graaf AW, Roelfsema F, Roos RA. Increased hypothalamic-pituitary-adrenal axis activity in Huntington's disease. The Journal of Clinical Endocrinology and Metabolism. 2009;94(4):1223-8.

[40] Vonsattel JP, Keller C, Del Pilar Amaya M. Neuropathology of Huntington's disease. Handb Clin Neurol. 2008;89:599618.

[41] de la Monte SM, Vonsattel JP, Richardson EP Jr. Morphometric demonstration of atrophic changes in the cerebral cortex, white matter, and neostriatum in Huntington's disease. Journal of Neuropathology and Experimental Neurology. 1988;47(5):516-25

[42] Vonsattel JP, Myers RH, Stevens TJ, Ferrante RJ, Bird ED, Richardson EP Jr. Neuropathological classification of Huntington's disease. Journal of Neuropathology and Experimental Neurology. 1985;44(6):559-77.

[43] Reiner A, Albin RL, Anderson KD, D'Amato CJ, Penney JB, Young AB. Differential loss of striatal projection neu- rons in Huntington disease. Proceedings of the National Academy of Sciences of the United States of America. 1988;85(15):5733-37.

[44] Albin RL, Reiner A, Anderson KD, Dure LSt, Handelin B, Balfour R, et al. Preferential loss of striato-external pallidal projection neurons in presymptomatic Huntington's disease. Annals of Neurology. 1992;31(4):425-30.

[45] Gerfen CR, Engber TM, Mahan LC, Susel Z, Chase TN, Monsma FJ Jr, et al. D1 and D2 dopamine receptor-regulated gene expression of striatonigral and striatopallidal neurons. Science. 1990;250(4986):1429-32

[46] Graybiel AM, Ragsdale CW Jr. Histochemically distinct compartments in the striatum of human, monkeys, and cat demonstrated by acetylthiocholinesterase staining. Proceedings of the National Academy of Sciences of the United States of America. 1978;75(11):5723-6.

[47] Goedert M, Mantyh PW, Emson PC, Hunt SP. Inverse relationship between neurotensin receptors and neurotensinlike immunoreactivity in cat striatum. Nature. 1984; 307(5951):543-6.

[48] Cote PY, Levitt P, Parent A. Distribution of limbic systemassociated membrane protein immunoreactivity in primate basal ganglia. Neuroscience. 1995;69(1):71-81.

[49] Joyce JN, Sapp DW, Marshall JF. Human striatal dopamine receptors are organized in compartments. Proceedings of the National Academy of Sciences of the United States of America. 1986;83(20):8002-6.

[50] Faull RL, Waldvogel HJ, Nicholson LF, Synek BJ. The distribution of GABAA-benzodiazepine receptors in the basal ganglia in Huntington's disease and in the quinolinic acidlesioned rat. Prog Brain Res. 1993;99:105-23.

[51] Dure LSt, Young AB, Penney JB. Excitatory amino acid binding sites in the caudate nucleus and frontal cortex of Huntington's disease. Annals of neurology. 1991;30(6):78593.

[52] Waldvogel HJ, Billinton A, White JH, Emson PC, Faull RL. Comparative cellular distribution of GABAA and GABAB receptors in the human basal ganglia: immunohistochemical colocalization of the alpha 1 subunit of the GABAA receptor, and the GABABR1 and GABABR2 receptor subunits. The Journal of comparative neurology. 2004;470(4): 339-56.

[53] Waldvogel HJ, Kubota Y, Fritschy J, Mohler H, Faull RL. Regional and cellular localisation of $\operatorname{GABA}(\mathrm{A})$ receptor subunits in the human basal ganglia: An autoradiographic and immunohistochemical study. The Journal of comparative neurology. 1999;415(3):313-40.

[54] Holt DJ, Graybiel AM, Saper CB. Neurochemical architecture of the human striatum. The Journal of comparative neurology. 1997;384(1):1-25.

[55] Holt DJ, Hersh LB, Saper CB. Cholinergic innervation in the human striatum: a three-compartment model. Neuroscience. 1996;74(1):67-87.

[56] Graybiel AM. Neurotransmitters and neuromodulators in the basal ganglia. Trends in neurosciences. 1990;13(7):24454.

[57] Prensa L, Gimenez-Amaya JM, Parent A. Chemical heterogeneity of the striosomal compartment in the human striatum. The Journal of comparative neurology. 1999;413(4):603-18

[58] Voorn P, Gerfen CR, Groenewegen HJ. Compartmental organization of the ventral striatum of the rat: immunohistochemical distribution of enkephalin, substance $\mathrm{P}$, dopamine, and calcium-binding protein. The Journal of comparative neurology. 1989;289(2):189-201. 
[59] Parent A, Fortin M, Cote PY, Cicchetti F. Calcium-binding proteins in primate basal ganglia. Neuroscience research. 1996;25(4):309-34.

[60] Manley MS, Young SJ, Groves PM. Compartmental organization of the peptide network in the human caudate nucleus. Journal of chemical neuroanatomy. 1994;7(3):191-201.

[61] Waldvogel HJ, Faull RL. Compartmentalization of parvalbumin immunoreactivity in the human striatum. Brain research. 1993;610(2):311-16

[62] Hedreen JC, Folstein SE. Early loss of neostriatal striosome neurons in Huntington's disease. Journal of neuropathology and experimental neurology. 1995;54(1):105-20.

[63] Morton AJ, Nicholson LF, Faull RL. Compartmental loss of NADPH diaphorase in the neuropil of the human striatum in Huntington's disease. Neuroscience. 1993;53(1):159-68.

[64] Augood SJ, Faull RL, Love DR, Emson PC. Reduction in enkephalin and substance P messenger RNA in the striatum of early grade Huntington's disease: a detailed cellular in situ hybridization study. Neuroscience. 1996;72(4):102336.

[65] Seto-Ohshima A, Emson PC, Lawson E, Mountjoy CQ, Carrasco LH. Loss of matrix calcium-binding proteincontaining neurons in Huntington's disease. Lancet. 1988;1(8597):1252-5.

[66] Ferrante RJ, Kowall NW, Beal MF, Martin JB, Bird ED, Richardson EP Jr. Morphologic and histochemical characteristics of a spared subset of striatal neurons in Huntington's disease. Journal of neuropathology and experimental neurology. 1987;46(1):12-27.

[67] Gerfen CR. The neostriatal mosaic: compartmentalization of corticostriatal input and striatonigral output systems. Nature. 1984;311(5985):461-4.

[68] Tokuno H, Chiken S, Kametani K, Moriizumi T. Efferent projections from the striatal patch compartment: anterograde degeneration after selective ablation of neurons expressing mu-opioid receptor in rats. Neurosci Lett. 2002;332(1):5-8.

[69] Fujiyama F, Sohn J, Nakano T, Furuta T, Nakamura KC, Matsuda W, et al. Exclusive and common targets of neostriatofugal projections of rat striosome neurons: a single neuron-tracing study using a viral vector. Eur J Neurosci. 2011;33(4):668-77.

[70] Parent A, Cote PY, Lavoie B. Chemical anatomy of primate basal ganglia. Progress in neurobiology. 1995;46(2-3):13197.

[71] Cudkowicz M, Kowall NW. Degeneration of pyramidal projection neurons in Huntington's disease cortex. Annals of neurology. 1990;27(2):200-4.

[72] Hedreen JC, Peyser CE, Folstein SE, Ross CA. Neuronal loss in layers V and VI of cerebral cortex in Huntington's disease. Neurosci Lett. 1991;133(2):257-61.

[73] Heinsen H, Strik M, Bauer M, Luther K, Ulmar G, Gangnus $\mathrm{D}$, et al. Cortical and striatal neurone number in Huntington's disease. Acta Neuropathol (Berl). 1994;88(4):320-33.

[74] Macdonald V, Halliday GM. Pyramidal cell loss in motor cortices in Huntington's disease. Neurobiol Dis. 2002;10(3):378-86.

[75] Macdonald V, Halliday GM, Trent RJ, McCusker EA. Significant loss of pyramidal neurons in the angular gyrus of patients with Huntington's disease. Neuropathol Appl Neurobiol. 1997;23(6):492-95.

[76] Rajkowska G, Selemon LD, Goldman-Rakic PS. Neuronal and glial somal size in the prefrontal cortex: a postmortem morphometric study of schizophrenia and Huntington disease. Arch Gen Psychiatry. 1998;55(3):215-24.
[77] Ruocco HH, Bonilha L, Li LM, Lopes-Cendes I, Cendes F. Longitudinal analysis of regional grey matter loss in Huntington disease: effects of the length of the expanded CAG repeat. J Neurol Neurosurg Psychiatry. 2008;79(2): 130-5.

[78] Bohanna I, Georgiou-Karistianis N, Egan GF. Connectivitybased segmentation of the striatum in Huntington's disease: vulnerability of motor pathways. Neurobiol Dis. 2011;42(3):475-81.

[79] Rosas HD, Hevelone ND, Zaleta AK, Greve DN, Salat DH, Fischl B. Regional cortical thinning in preclinical Huntington disease and its relationship to cognition. Neurology. 2005;65(5):745-7.

[80] Rosas HD, Tuch DS, Hevelone ND, Zaleta AK, Vangel M, Hersch SM, et al. Diffusion tensor imaging in presymptomatic and early Huntington's disease: Selective white matter pathology and its relationship to clinical measures. Mov Disord. 2006;21(9):1317-25.

[81] Tabrizi SJ, Langbehn DR, Leavitt BR, Roos RA, Durr A, Craufurd D, et al. Biological and clinical manifestations of Huntington's disease in the longitudinal TRACK-HD study: cross-sectional analysis of baseline data. Lancet Neurol. 2009;8(9):791-801.

[82] Gomez-Anson B, Alegret M, Munoz E, Monte GC, Alayrach E, Sanchez A, et al. Prefrontal cortex volume reduction on MRI in preclinical Huntington's disease relates to visuomotor performance and CAG number. Parkinsonism Relat Disord. 2009;15(3):213-9.

[83] Nopoulos P, Aylward EH, Ross CA, Johnson HJ, Magnotta VA, Juhl AR, et al. Cerebral cortex structure in prodromal Huntington disease. Neurobiol Dis. 2010;40(3):544-54.

[84] Arrasate M, Mitra S, Schweitzer ES, Segal MR, Finkbeiner S. Inclusion body formation reduces levels of mutant huntingtin and the risk of neuronal death. Nature. 2004; 431(7010):805-10.

[85] Reiner A, Del Mar N, Deng YP, Meade CA, Sun Z, Goldowitz D. R6/2 neurons with intranuclear inclusions survive for prolonged periods in the brains of chimeric mice. The Journal of comparative neurology. 2007;505(6):60329.

[86] Davies SW, Turmaine M, Cozens BA, Raza AS, Mahal A, Mangiarini L, et al. From neuronal inclusions to neurodegeneration: neuropathological investigation of a transgenic mouse model of Huntington's disease. Philos Trans R Soc Lond B Biol Sci. 1999;354(1386):981-9.

[87] Davies SW, Turmaine M, Cozens BA, DiFiglia M, Sharp $\mathrm{AH}$, Ross CA, et al. Formation of neuronal intranuclear inclusions underlies the neurological dysfunction in mice transgenic for the HD mutation. Cell. 1997;90(3):537-48.

[88] Perutz MF, Johnson T, Suzuki M, Finch JT. Glutamine repeats as polar zippers: their possible role in inherited neurodegenerative diseases. Proceedings of the National Academy of Sciences of the United States of America. 1994;91(12):5355-8.

[89] Perutz MF. Glutamine repeats and inherited neurodegenerative diseases: molecular aspects. Current opinion in structural biology. 1996;6(6):848-58.

[90] DiFiglia M, Sapp E, Chase K, Schwarz C, Meloni A, Young $\mathrm{C}$, et al. Huntingtin is a cytoplasmic protein associated with vesicles in human and rat brain neurons. Neuron. 1995;14(5):1075-81.

[91] DiFiglia M, Sapp E, Chase KO, Davies SW, Bates GP, Vonsattel JP, et al. Aggregation of huntingtin in neuronal intranuclear inclusions and dystrophic neurites in brain. Science. 1997;277(5334):1990-3. 
[92] Gutekunst CA, Li SH, Yi H, Mulroy JS, Kuemmerle S, Jones R, et al. Nuclear and neuropil aggregates in Huntington's disease: relationship to neuropathology. J Neurosci. 1999;19(7):2522-34.

[93] Maat-Schieman ML, Dorsman JC, Smoor MA, Siesling S, Van Duinen SG, Verschuuren JJ, et al. Distribution of inclusions in neuronal nuclei and dystrophic neurites in Huntington disease brain. Journal of neuropathology and experimental neurology. 1999;58(2):129-37.

[94] Becher MW, Kotzuk JA, Sharp AH, Davies SW, Bates GP, Price DL, et al. Intranuclear neuronal inclusions in Huntington's disease and dentatorubral and pallidoluysian atrophy: correlation between the density of inclusions and IT15 CAG triplet repeat length. Neurobiol Dis. 1998;4(6):387-97.

[95] Herndon ES, Hladik CL, Shang P, Burns DK, Raisanen J, White CL 3rd. Neuroanatomic profile of polyglutamine immunoreactivity in Huntington disease brains. Journal of Neuropathology and Experimental Neurology. 2009;68(3):250-61.

[96] van Roon-Mom WM, Hogg VM, Tippett LJ, Faull RL. Aggregate distribution in frontal and motor cortex in Huntington's disease brain. Neuroreport. 2006;17(6):667-70.

[97] Lievens JC, Iche M, Laval M, Faivre-Sarrailh C, Birman S. AKT-sensitive or insensitive pathways of toxicity in glial cells and neurons in Drosophila models of Huntington's disease. Human molecular genetics. 2008;17(6): 882-94.

[98] Weiss A, Roscic A, Paganetti P. Inducible mutant huntingtin expression in HN10 cells reproduces Huntington's diseaselike neuronal dysfunction. Molecular neurodegeneration. 2009;4:11

[99] Kitamura A, Kubota H, Pack CG, Matsumoto G, Hirayama $\mathrm{S}$, Takahashi Y, et al. Cytosolic chaperonin prevents polyglutamine toxicity with altering the aggregation state. Nature cell biology. 2006;8(10):1163-70.

[100] Ratovitski T, Gucek M, Jiang H, Chighladze E, Waldron E, D'Ambola J, et al. Mutant huntingtin N-terminal fragments of specific size mediate aggregation and toxicity in neuronal cells. The Journal of biological chemistry. 2009;284(16):10855-67.

[101] Saudou F, Finkbeiner S, Devys D, Greenberg ME. Huntingtin acts in the nucleus to induce apoptosis but death does not correlate with the formation of intranuclear inclusions. Cell. 1998;95(1):55-66.

[102] White JK, Auerbach W, Duyao MP, Vonsattel JP, Gusella JF, Joyner AL, et al. Huntingtin is required for neurogenesis and is not impaired by the Huntington's disease CAG expansion. Nature genetics. 1997;17(4):404-10.

[103] Kaltenbach LS, Romero E, Becklin RR, Chettier R, Bell $\mathrm{R}$, Phansalkar A, et al. Huntingtin interacting proteins are genetic modifiers of neurodegeneration. PLoS genetics. 2007;3(5):e82.

[104] Landles C, Bates GP. Huntingtin and the molecular pathogenesis of Huntington's disease. Fourth in molecular medicine review series. EMBO reports. 2004;5(10): 958-63.

[105] Ross CA, Poirier MA. Protein aggregation and neurodegenerative disease. Nature medicine. 2004;10Suppl: S10-7.

[106] Kuemmerle S, Gutekunst CA, Klein AM, Li XJ, Li SH, Beal MF, et al. Huntington aggregates may not predict neuronal death in Huntington's disease. Annals of neurology. 1999;46(6):842-9.

[107] Fusco FR, Chen Q, Lamoreaux WJ, Figueredo-Cardenas G, Jiao Y, Coffman JA, et al. Cellular localization of huntingtin in striatal and cortical neurons in rats: lack of correlation with neuronal vulnerability in Huntington's disease. J Neurosci. 1999;19(4):1189-202.

[108] Yamamoto A, Lucas JJ, Hen R. Reversal of neuropathology and motor dysfunction in a conditional model of Huntington's disease. Cell. 2000;101(1):57-66.

[109] Schiefer J, Landwehrmeyer GB, Luesse HG, Sprunken A, Puls C, Milkereit A, et al. Riluzole prolongs survival time and alters nuclear inclusion formation in a transgenic mouse model of Huntington's disease. Mov Disord. 2002;17(4):748-57.

[110] Rodriguez-Lebron E, Denovan-Wright EM, Nash K, Lewin AS, Mandel RJ. Intrastriatal rAAV-mediated delivery of anti-huntingtin shRNAs induces partial reversal of disease progression in R6/1 Huntington's disease transgenic mice. Molecular therapy: the journal of the American Society of Gene Therapy. 2005;12(4):618-33.

[111] Machida Y, Okada T, Kurosawa M, Oyama F, Ozawa $\mathrm{K}$, Nukina N. rAAV-mediated shRNA ameliorated neuropathology in Huntington disease model mouse. Biochemical and biophysical research communications. 2006;343(1):190-7.

[112] Reading SA, Dziorny AC, Peroutka LA, Schreiber M, Gourley LM, Yallapragada V, et al. Functional brain changes in presymptomatic Huntington's disease. Annals of neurology. 2004;55(6):879-83.

[113] Laforet GA, Sapp E, Chase K, McIntyre C, Boyce FM, Campbell M, et al. Changes in cortical and striatal neurons predict behavioral and electrophysiological abnormalities in a transgenic murine model of Huntington's disease. J Neurosci. 2001;21(23):9112-23.

[114] Cammarata S, Caponnetto C, Tabaton M. Ubiquitin-reactive neurites in cerebral cortex of subjects with Huntington's chorea: a pathological correlate of dementia? Neurosci Lett. 1993;156(1-2):96-8.

[115] Sapp E, Penney J, Young A, Aronin N, Vonsattel JP, DiFiglia M. Axonal transport of N-terminal huntingtin suggests early pathology of corticostriatal projections in Huntington disease. Journal of neuropathology and experimental neurology. 1999;58(2):165-73

[116] Sieradzan KA, Mann DM. The selective vulnerability of nerve cells in Huntington's disease. Neuropathol Appl Neurobiol. 2001;27(1):1-21.

[117] Hodges A, Strand AD, Aragaki AK, Kuhn A, Sengstag $\mathrm{T}$, Hughes $\mathrm{G}$, et al. Regional and cellular gene expression changes in human Huntington's disease brain. Human molecular genetics. 2006;15(6):965-77.

[118] Sotrel A, Williams RS, Kaufmann WE, Myers RH.Evidence for neuronal degeneration and dendritic plasticity in cortical pyramidal neurons of Huntington's disease: a quantitative Golgi study. Neurology. 1993;43(10):2088-96.

[119] Cepeda C, Wu N, Andre VM, Cummings DM, Levine MS. The corticostriatal pathway in Huntington's disease. Progress in Neurobiology. 2007;81(5-6):253-71.

[120] Cepeda C, Hurst RS, Calvert CR, Hernandez-Echeagaray E, Nguyen OK, Jocoy E, et al. Transient and progressive electrophysiological alterations in the corticostriatal pathway in a mouse model of Huntington's disease. J Neurosci. 2003;23(3):961-9.

[121] Milnerwood AJ, Raymond LA. Corticostriatal synaptic function in mouse models of Huntington's disease: early effects of huntingtin repeat length and protein load. J Physiol. 2007;585(Pt 3):817-31.

[122] Andre VM, Cepeda C, Venegas A, Gomez Y, Levine MS Altered cortical glutamate receptor function in the R6/2 
model of Huntington's disease. J Neurophysiol. 2006;95(4): 2108-19.

[123] Spampanato J, Gu X, Yang XW, Mody I. Progressive synaptic pathology of motor cortical neurons in a BAC transgenic mouse model of Huntington's disease. Neuroscience. 2008;157(3):606-20.

[124] Zeron MM, Hansson O, Chen N, Wellington CL, Leavitt $\mathrm{BR}$, Brundin $\mathrm{P}$, et al. Increased sensitivity to N-methylD-aspartate receptor-mediated excitotoxicity in a mouse model of Huntington's disease. Neuron. 2002;33(6): 849-60.

[125] Strand AD, Baquet ZC, Aragaki AK, Holmans PA, Yang L, Cleren C, et al. Expression profiling of Huntington's disease models suggests that brain-derived neurotrophic factor depletion plays a major role in striatal degeneration. J Neurosci. 2007;27(43):11758-68.

[126] Baquet ZC, Gorski JA, Jones KR. Early striatal dendrite deficits followed by neuron loss with advanced age in the absence of anterograde cortical brain-derived neurotrophic factor. J Neurosci. 2004;24(17):4250-8.

[127] Altar CA, Cai N, Bliven T, Juhasz M, Conner JM, Acheson $\mathrm{AL}$, et al. Anterograde transport of brain-derived neurotrophic factor and its role in the brain. Nature. 1997; 389(6653):856-60.

[128] Conner JM, Lauterborn JC, Yan Q, Gall CM, Varon S. Distribution of brain-derived neurotrophic factor (BDNF) protein and mRNA in the normal adult rat CNS: evidence for anterograde axonal transport. J Neurosci. 1997;17(7):2295-313.
[129] Cattaneo E, Rigamonti D, Goffredo D, Zuccato C, Squitieri F, Sipione S. Loss of normal huntingtin function: new developments in Huntington's disease research. Trends in neurosciences. 2001;24(3):182-8.

[130] Zuccato C, Ciammola A, Rigamonti D, Leavitt BR, Goffredo D, Conti L, et al. Loss of huntingtin-mediated BDNF gene transcription in Huntington's disease. Science. 2001;293(5529):493-8.

[131] Ferrer I, Goutan E, Marin C, Rey MJ, Ribalta T. Brainderived neurotrophic factor in Huntington disease. Brain research. 2000;866(1-2):257-61.

[132] Gambazzi L, Gokce O, Seredenina T, Katsyuba E, Runne H, Markram H, et al. Diminished activity-dependent brainderived neurotrophic factor expression underlies cortical neuron microcircuit hypoconnectivity resulting from exposure to mutant huntingtin fragments. J Pharmacol Exp Ther. 2010;335(1):13-22

[133] Cha JH. Transcriptional dysregulation in Huntington's disease. Trends in neurosciences. 2000;23(9):387-92.

[134] Morton AJ, Faull RL, Edwardson JM. Abnormalities in the synaptic vesicle fusion machinery in Huntington's disease. Brain Res Bull. 2001;56(2):111-7.

[135] Petersen A, Mani K, Brundin P. Recent advances on the pathogenesis of Huntington's disease. Exp Neurol. 1999;157(1):1-18 